\title{
Lifestyle of a Roman Imperial community: ethnobotanical evidence from dental calculus of the Ager Curensis inhabitants
}

\author{
Alessia D’Agostino ${ }^{1 \dagger}$, Angelo Gismondi ${ }^{1 * \dagger} \mathbb{D}$, Gabriele Di Marco ${ }^{1}$, Mauro Lo Castro², Rosaria Olevano², Tiziano Cinti ${ }^{2}$, \\ Donatella Leonardi ${ }^{1}$ and Antonella Canini ${ }^{1}$ (1)
}

\begin{abstract}
Background: The analysis of ancient calcified dental plaque is a powerful archaeobotanical method to elucidate the key role of the plants in human history.

Methods: In this research, by applying both optic microscopy and gas chromatography mass spectrometry on this matrix, a detailed qualitative investigation for reconstructing the lifestyle of a Roman imperial community of the Ager Curensis (Sabina Tiberina, Central Italy) was performed.

Results: The detection of animal micro-remains and molecules (e.g., hairs, feather barbules, markers of dairy products), starch granules of several cereals and legumes, pollen (e.g., Juglans regia L., Hedera sp. L.) and other plant micro-debris (e.g., trichome of Olea sp., hemp fibers), and phytochemicals (e.g., Brassicaceae, Lamiaceae herbs, Ferula sp., Trigonella foenum-graecum L., wine, and Humulus lupulus L.) in the dental calculus sample demonstrated that plant-derived foods were regularly consumed together with animal resources.
\end{abstract}

Conclusions: This nutritional plan, consistent with the information reported in ancient written texts, suggested that the studied population based its own subsistence on both agriculture and husbandry, probably also including beekeeping and hunting activities. All together, these results represent proofs for the comprehension of food habits, phytotherapeutic practices, and cultural traditions of one of the first Roman settlements in the Sabina Tiberina area.

Keywords: Dental calculus, Cereals, Non-dietary micro-remains, Secondary metabolites, Light microscopy, Gas chromatography mass spectrometry, Passo Corese

\section{Background}

In 2015, a Roman necropolis has been discovered near the town of Passo Corese $\left(42^{\circ} 9^{\prime} 23.68^{\prime \prime} \mathrm{N}, 12^{\circ} 38^{\prime}\right.$ 53.51" E; Fara in Sabina, Latium, Italy) (Fig. 1a, b). In this archaeological context, 42 tombs of several typologies (e.g., "cappuccina" burials, simple burials) were identified. Radiocarbon dating, performed at the Centre for Diagnostic and Dating (CEDAD, University of Salento) on human bones, has revealed that the burial

\footnotetext{
* Correspondence: gismondi@scienze.uniroma2.it

${ }^{+}$Alessia D'Agostino and Angelo Gismondi are co-first authors as they equally contributed to this work

'Department of Biology, University of Rome "Tor Vergata", Via della Ricerca Scientifica 1, 00133 Rome, Italy

Full list of author information is available at the end of the article
}

ground was in use between the first and the third century AD.

Several reports have documented the presence of numerous settlements in the geographic region where the necropolis was unearthed. In that rural territory, Cures was considered the main inhabitant center of the Ager Curensis (Sabina Tiberina, Central Italy), a hilly area located at about $40 \mathrm{~km}$ from Rome [1-3]. As Via Salaria and Tiber River represented the most important commercial arterial roads of the region, Cures gained a hegemonic role at Roman times. The policies of Sulla, Caesar, and Augustus promoted the repopulation of the countryside along the Tiber valley, during the following historical periods, favoring the development of rustic villas with the aim to exploit the local agricultural

(C) The Author(s). 2019 Open Access This article is distributed under the terms of the Creative Commons Attribution 4.0 International License (http://creativecommons.org/licenses/by/4.0/), which permits unrestricted use, distribution, and 

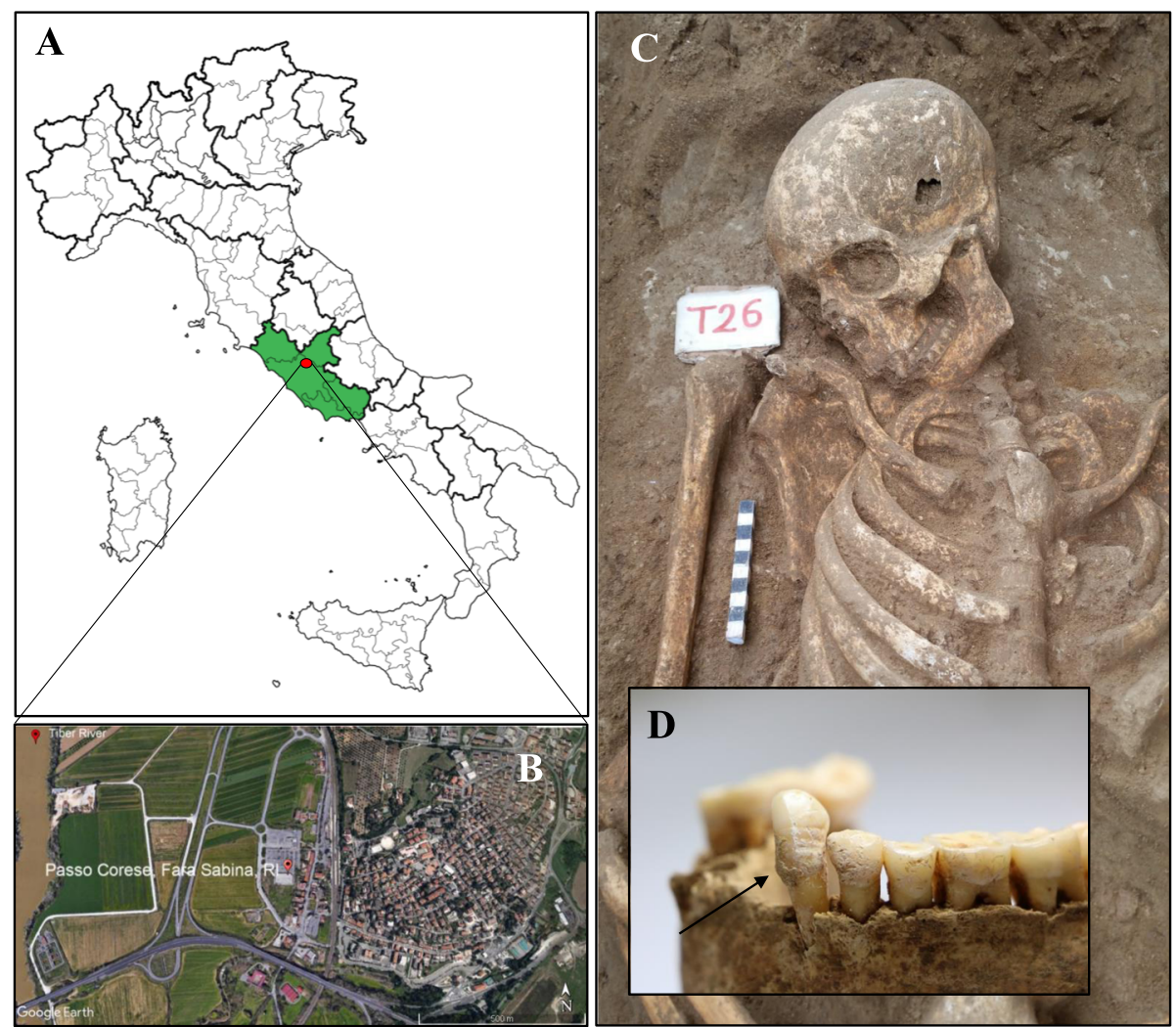

Fig. 1 Location of Passo Corese (Fara Sabina, Latium) and inhumation of the burial 26. Map of Italy with the geographical location of the studied site (a and $\mathbf{b}$, image from Google Earth); representative image of human skeletal remains (c) and detail of the relative mandibular dental calculus (d)

resources [4]. Therefore, the studied necropolis, discovered during excavations of preventive archaeology, could be connected to one of these small villages, whose archaeological remains have not been found yet. The agrarian system at Roman times was very complex, and the selection criteria of the crops were influenced by multiple factors: soil fertility, climate, and ease of storability, processing and yield. Cereals represented the most extensively cultivated crops in Italy. Among them, wheat was the most used, while millet was grown on marginal soils or as summer crop in rotation to other species. In addition, the diet of middle and lower classes also included hemmer, spelt, and barley [5-9]. Beyond the "Mediterranean triad" (grain, olive oil, and wine), the legumes (e.g., peas, chickpeas, lentils, broad beans) were important food sources, especially for Italian rural communities. In particular, they were eaten alone or mixed with wheat or millet [10]. Meat, deriving primarily from poultry, goat, sheep, pork, game, and fish, was mainly associated to festive occasions. In contrast, dairy products and eggs represented the most common animal protein sources, mostly in the sylvo-pastoral economy of hilly regions $[5,6,10]$. Vegetables, like Brassicaceae, onions, and garlic, were complements for poor dishes [5]. A wide variety of fruits and seeds, such as figs, pomegranates, dates, almonds, chestnuts, and walnuts, were abundantly consumed $[6,8,11]$. Wine, beer, and mead (produced by fermentation of grape, malted cereals, and honey, respectively) were the most popular beverages, with also religious and medical value [12, 13]. Beyond food, the ethnobotanical knowledge similarly provided both natural drugs and raw materials, highlighting the key role of the plant kingdom in the ancient world [1416]. To date, no scientific data testify the economic condition and/or the dietary pattern of the Sabinian communities, including the differences among social classes. However, recent archaeobotanical records contradicted the common idea that some foodstuffs were not available for the lower class, probably due to optimal geographical location, that is access to trades and land fertility [11]. According to all this evidence, the objective of the present research was the investigation of the lifestyle adopted by a Roman community of the Ager Curensis. A combined approach between morphological analysis and gas chromatography mass spectrometry was applied on dental plaque, to gain information about the main sources of carbohydrates and the use of edible and/or medicinal plant species by this population. The 
employment of such type of blended strategy, rarely carried out in literature [17], provided interesting insights on diet and agriculture in Roman central Italy.

\section{Methods \\ Sampling}

Archaeological excavations, performed between November and December 2015 and conducted in an area adjacent to the railway station of Passo Corese (Fara in Sabina, Italy), unearthed a Roman necropolis (first-third century AD). Forty-two human skeletons were collected, examined per sex and age at death, and preserved at the "Museo Civico Naturalistico dei Monti Prenestini" (Capranica Prenestina, Rome, Italy). A total of 27 individuals were subjected to dental calculus investigation. Wearing starch-free gloves and using sodium hydroxide (2\%) to cleanse tools and work surfaces and reduce contamination, supragingival calculus flakes were removed by an autoclaved metal dental pick from the tooth surface of the inhumates (Fig. 1c, d). In the laboratories of Botany (University of Rome "Tor Vergata," Italy), specifically reserved to the analysis of ancient biomolecules [18] (where contamination controls were regularly carried out on workspaces, instruments, and supplies), decontamination and sterilization protocols of the mineralized plaque were conducted. In detail, under a sterile vertical laminar flow hood (Heraeus HERAsafe HS12 Type), dental calculus was treated by UV light for $10 \mathrm{~min}$, immersed in $2 \%$ sodium hydroxide for $15 \mathrm{~min}$, washed with sterilized water, and dried at $37{ }^{\circ} \mathrm{C}$. To guarantee that environmental contaminants were eliminated, 8 calculus samples were randomly individuated and processed, before and after the cleaning procedures, as follows. Each sample was resuspended in $200 \mu \mathrm{L}$ of sterilized water, in agitation, for $15 \mathrm{~min}$ and directly subjected to light microscopy observation. The results of the control tests (obtained from not decontaminated samples) were reported in Additional file 1. No microremain was detected in the samples exposed to decontamination protocols.

\section{Morphological analysis}

To isolate micro-debris from the mineral matrix of the dental plaque (10 $\mathrm{mg}$ per sample), after dissolving the calculus in $0.2 \mathrm{M}$ hydrochloric acid for $8 \mathrm{~h}$ and performing three washes with sterilized ultrapure water, the pellet was resuspended in $100 \mu \mathrm{L}$ of bidistilled water and glycerol (1:1), under a sterile hood, and placed on glass slides to be analyzed at optic microscopy (Nikon Eclipse E100). Each micro-remain was observed under white and polarized light, photographed and measured in size by ProgRes CapturePro 2.9.0.1 software. Modern reference image library expressly produced for the identification of animal and plant debris, the laboratory starch experimental collection [19] and literature data were consulted for the taxonomic determination of the ancient pollen and micro-remains [17, 20-24].

\section{Gas chromatographic mass spectrometry analysis}

A qualitative gas chromatographic approach was developed in the present work and applied on ancient dental calculus, as reported. In detail, $10 \mathrm{mg}$ of sample was solubilized in $0.5 \mathrm{~mL}$ of $3 \%$ hydrochloric acid, overnight. A volume of hexane was added and incubated for $2 \mathrm{~h}$, in agitation. After centrifugation at maximum speed, for 10 min, the hexane fraction was collected, dried out (speedvac system, Eppendorf AG 22331 Hamburg, Concentration Plus) and derivatized with $60 \mu \mathrm{L}$ of hexane and 40 $\mu \mathrm{L}$ of the Methyl-8-Reagent (v/v; Thermo Scientific), as reported in the manufacturer's guidelines. The analysis was performed in a GC-MS QP2010 system (Shimadzu, Japan) equipped with a DB-5 column (Phenomenex; length $30 \mathrm{~m} \times$ diameter $0.25 \mathrm{~mm} \times$ thickness $0.25 \mu \mathrm{m}$ ), in triplicate per each sample. The temperature gradient was set as follows: $60^{\circ} \mathrm{C}$ for $5 \mathrm{~min}$ and then, at a rate of $6{ }^{\circ} \mathrm{C} / \mathrm{min}$, the oven reached $150{ }^{\circ} \mathrm{C}$ for $5 \mathrm{~min}, 250{ }^{\circ} \mathrm{C}$ for $5 \mathrm{~min}$ and $330{ }^{\circ} \mathrm{C}$ for $25 \mathrm{~min}$. Helium was employed as carrier gas, at a constant flow of $1 \mathrm{~mL} / \mathrm{min}$. The mass spectrum was obtained by electron impact (EI) at $70 \mathrm{eV}$ (scanning from 100 to $700 \mathrm{~m} / \mathrm{z}$ ), ion source and interface temperatures were $230{ }^{\circ} \mathrm{C}$ and $320^{\circ} \mathrm{C}$, respectively, and solvent cut time was equal to $6 \mathrm{~min}$. The identification of each molecule was carried out by comparing its mass spectrum with those registered in the NIST Library 14 (similarity values higher than $85 \%$ ) and on line support [25]. Plant species and food categories ingested by the individuals, at least once during their lifetime, were inferred associating the detected analytes through literature data and scientific food databases [26, 27].

\section{Results and discussion}

Ancient mineralized dental plaque, or dental calculus, is a valuable matrix which is widely employed in archaeological contexts from the 1970s. The plant microremains, embedded in this deposit, recorded the variation of the ethnobotanical use of plant species in history [24, 28-34]. The etiology of dental calculus is multifactorial, and individual genetic predisposition, diet pattern, and oral hygiene practices are the most important factors influencing its development. The chemical composition of calculus flakes consists of inorganic salts deriving from saliva, ingested food molecules, and residues of oral microorganisms [35]. Moreover, this ancient deposit can provide additional cultural and environmental information. Indeed, various published works stated the existence of alternative pathways (e.g., accidental or intentional inhalation) for the absorption of dietary and non-dietary debris in tartar $[19,36,37]$. In the present 
study, dietary customs, phytotherapeutic practices, and other activities besides food of a Roman imperial community of the Ager Curensis (first-third century AD) were explored. No significant difference was detected among the samples, according to sex and age at death.

\section{Morphological analysis Starch granules}

Optic microscopy revealed the presence of 571 starch grains in all samples (Table 1), some of them shown in Fig. 2. They were clustered into 6 morphotypes and described (Table 2) according to aggregation level (i.e., simple or compound), shape, size, presence of lamellae and hilum, cracks, and other surface features, and using the international nomenclature code [38] and the starch reference collection hosted in the laboratory of Botany (University of Rome “Tor Vergata," Italy) [19]. Eleven starches (morphotype I, Table 2) displayed traits consistent with those of legumes (e.g., reniform shape and characteristic longitudinal cleft fissure). In particular, some of them were recognized as Pisum sp. L. (e.g., pea) and Vicia sp. L. (e.g., broad bean) starch granules, both important sources of proteins for ancient rural communities [39]. On the basis of morphological characteristics (e.g., pyriform shape and size), 11 granules (morphotype II, Table 2) were likely attributable to Quercus sp. L. (Fagaceae), typical trees of Mediterranean scrub; the acorns, indeed, were used as foodstuff in famine periods [40]. About these seeds, Pliny the Elder stated in his Naturalis Historia $(16,15)$ that they were more palatable if baked. All remaining starches were ascribable to the Poaceae family. Fifty-three polyhedral granules (morphotype III, Table 2), mainly detected in aggregates, were identified as starch sub-units of Poeae caryopses, such as Avena sp. L. (e.g., oats). Moreover, 43 ancient starches were assigned to the Paniceae tribe (morphotype IV, Table 2). In detail, these last grains appeared in form of sub-units which showed a faceted surface and radial fissures typical of Setaria sp. P. Beauv. (foxtail millet) and Panicum sp. L. (millet) starches. Indeed, in Roman times, millet was common ingredient for gruels, while oats also for preparing of malted beers [41, 42]. One hundred and fifty-seven micro-remains (morphotype $\mathrm{V}$, Table 2) corresponded to starches characteristic for Triticeae grasses (i.e., Hordeum L. and Triticum sp.). These cereals were employed as main components of breads and porridges [42]. In particular, Triticum dicoccum L., the emmer wheat, was the most widely cultivated and appreciated crop at that time in Italy [6]. Finally, the last morphotype included 112 starch granules (morphotype VI, Table 2) which displayed morphological and morphometric parameters coherent with those of Sorghum sp. Moench. The detection of sorghum suggested import from Africa or direct cultivation of this species in the
Roman Empire [41, 43-45]. On the other hand, 184 starches were not taxonomically determined because of lacking diagnostic features. Probably, they were subjected to cooking procedures or enzyme degradation [46].

\section{Other plant micro-remains}

In the samples, a total of six pollen grains were found (Table 1), although two of them were not taxonomically identifiable. The first pollen appeared circular in polar view, medium-sized $(35 \mu \mathrm{m})$, and polypantoporate (more than 6 apertures with circular germination pores); it was attributed to Juglans regia L. (Fig. 3) [47]. The second one was recognized as Castanea Mill. pollen grain, according to its aperture condition (tricolporate), shape (prolate), and length $(16 \mu \mathrm{m})$. Another one displayed some traits consistent with those of Hedera pollen; indeed, it was tricolporate, medium-sized $(30 \mu \mathrm{m})$, characterized by an exine with reticulate ornamentation and a spheroidal and subtriangular shape in polar view (Fig. 3). The last one was isopolar, spheroidal (equatorial diameter, $22 \mu \mathrm{m}$ ), and with reticulate exine; these elements suggested the affinity of this pollen with Oleaceae ones. The pollen grains embedded in the dental calculus, as a consequence of possible accidental aspiration due to breathing, may testify the existence of the relative plant species in the past environments [19, 36]. Indeed, Juglans regia, Castanea sativa Mill., and Olea europaea L. were already diffused in the Mediterranean landscape and highly appreciated by the Romans for their timber and fruits [48, 49]. However, pollen could also be remained entrapped in tartar after ingestion processes. In this regard, it is important to remind that the floral portions of walnut were employed in traditional medicine to treat malaria and rheumatic pains, while chestnut flower extracts as antispasmodic and anti-dysenteric [50, 51]. Last but not least, both honey and other beehive products cannot be excluded as sources of pollen from nectariferous plants, such as chestnut and ivy. Certainly, these matrices were used, in history, not only as sweeteners and food preservatives but also like a powerful natural remedy [52, 53].

In total, 11 plant fibers were recovered from the dental calculus (Table 1, Fig. 3). Under optic microscope, these micro-remains appeared flat, multifibrillar, and not helicoidal, and are characterized by dislocations (or Xnodes) repeated along the strand. Moreover, a Z-twist fibrillar orientation was distinguishable. According to this evidence, the laboratory reference collections for fibers, literature data $[54,55]$, and both the cultural and chronological context [56-58], all micro-debris could be considered as residues of Cannabaceae plant tissue, most likely hemp. Hemp fibers, obtained by maceration and consequent desiccation of Cannabis L. phloem, were 


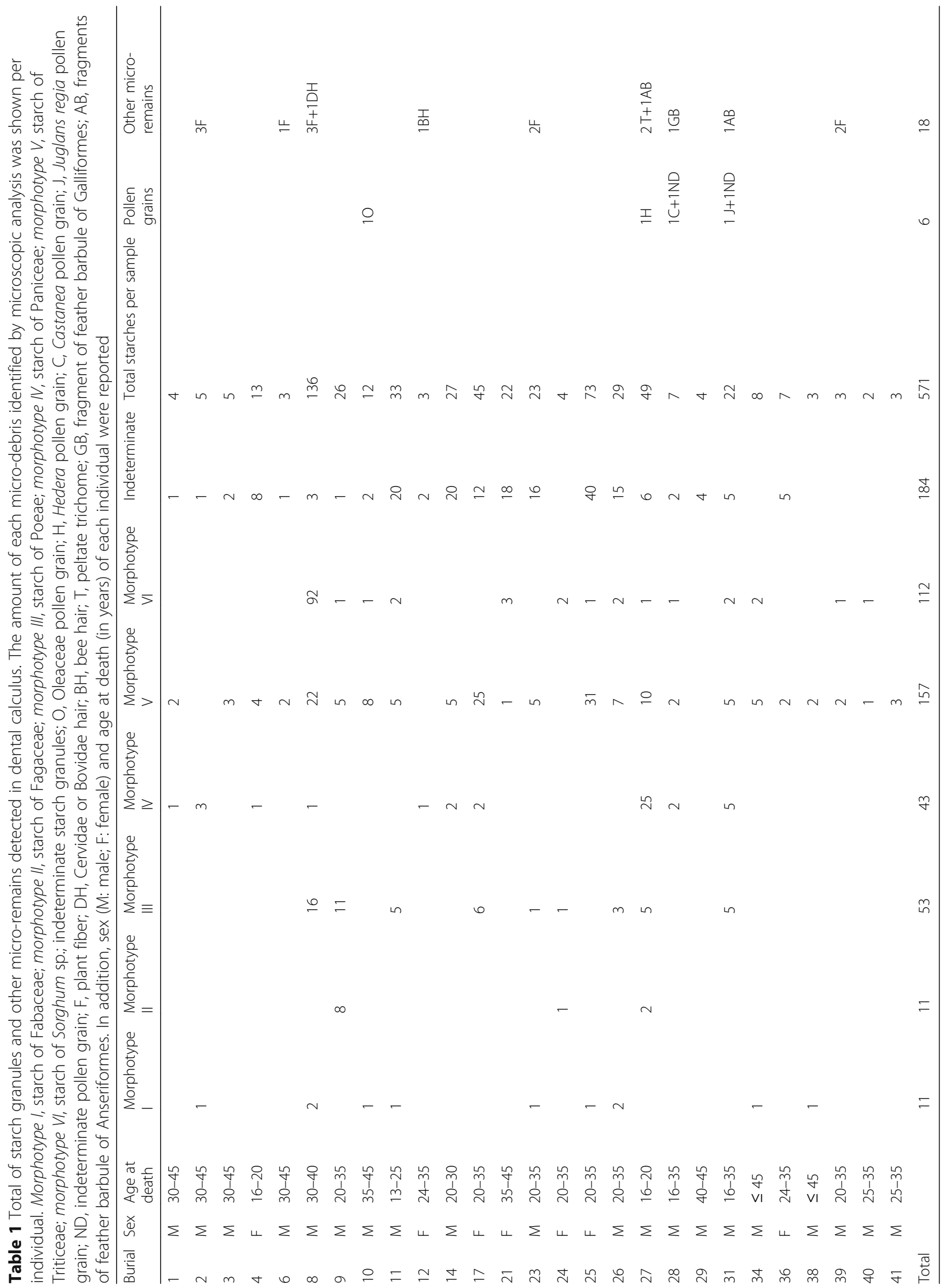




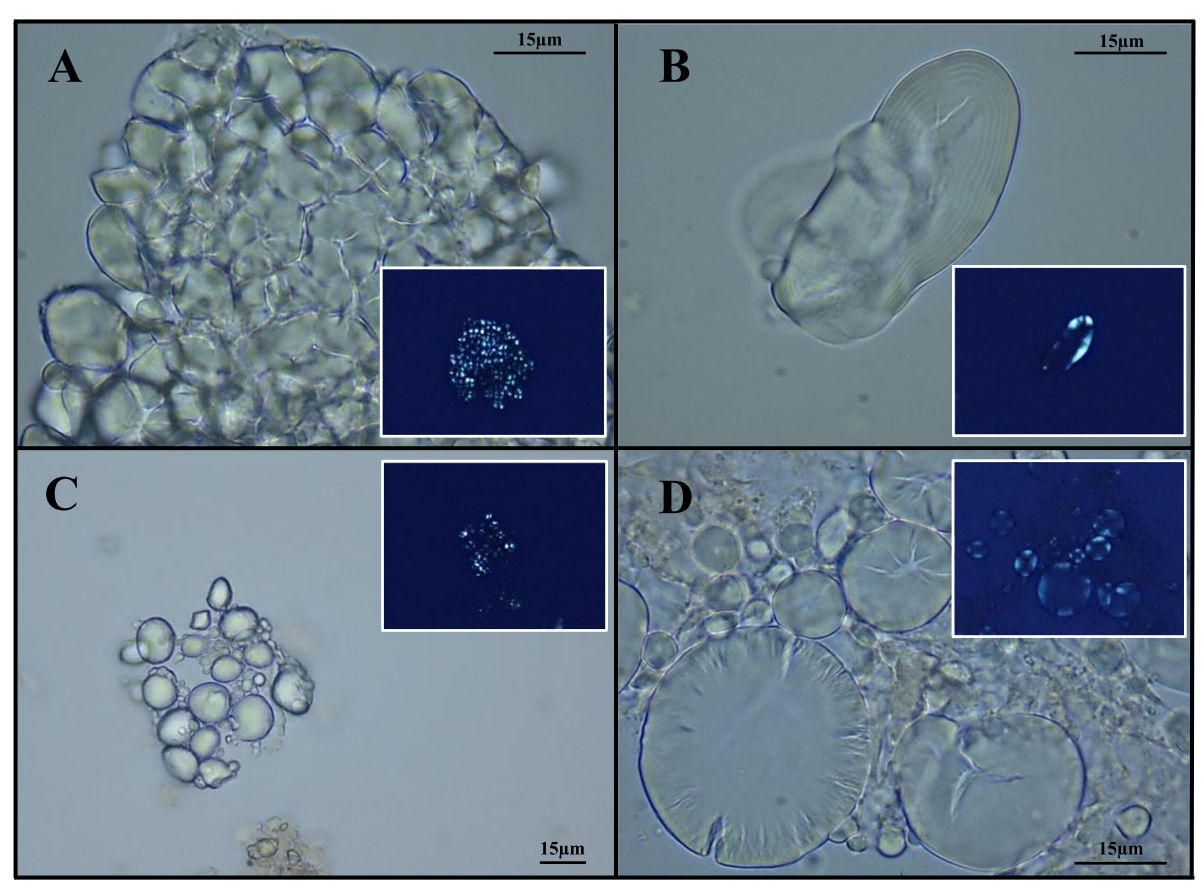

Fig. 2 Ancient starch granules at optic microscopy. Representative images of starches found in dental calculus samples: aggregate of Sorghum sp. starch grains and relative polarized image $(\mathbf{a})$; starch grain of Fabaceae and relative polarized image $(\mathbf{b})$; aggregates of Triticeae starch grains and relative polarized images (c and $\mathbf{d}$ )

used in the Roman period to produce clothes, canvasses, bags, and tough ropes (e.g., for hunting nets) [59-61]. The presence of hemp fibers in the ancient dental calculus might be justified by (i) inhalation during its processing activity [62], (ii) ingestion of food and beverages preserved by hemp sacks [52], and (iii) intake of hemp exudates and extracts for therapeutic purposes. In the second century AD, Galen mentioned the use of sweets containing Cannabis to induce hilarity [63]. However, ancient written sources are discordant about the possibility that the Romans knew the medicinal effects of this species [64].

In the dental plaque of one individual, the presence of two non-glandular trichomes of olive (Olea sp. L.) leaf were identified (Table 1, Fig. 3). The detection of these superficial multicellular peltate hairs suggested their accidental inhalation or the traditional use of olive leaves as mouth cleanser or in decoction for treating gastrointestinal diseases, urinary infections, bronchial asthma, and hypertension, a practice widely adopted by the

Table 2 Starch morphotypes. Detailed description of the starch morphotypes recovered from the dental calculus of the ancient community

\begin{tabular}{|c|c|c|}
\hline Morphotype & Morphologic and morphometric description & $\begin{array}{l}\text { Taxonomic } \\
\text { group }\end{array}$ \\
\hline I & $\begin{array}{l}\text { Irregular ovoid to reniform granules; size range. } 20-52 \mu \mathrm{m} \text { in length and } 17-38 \mu \mathrm{m} \text { in width; clear concentric lamellae; } \\
\text { hilum is obscured; presence of a longitudinal cleft }\end{array}$ & Fabaceae \\
\hline$\|$ & $\begin{array}{l}\text { Pyriform to reniform granules; size range, } 19-35 \mu \mathrm{m} \text { in length and } 16-27 \mu \mathrm{m} \text { in width; faintly visible lamellae; invisible } \\
\text { hilum }\end{array}$ & Fagaceae \\
\hline III & $\begin{array}{l}\text { Multifaceted polyhedral units on one side and dome shaped on the other one; individual granule size, 5-14 } \mu \mathrm{m} \text { in } \\
\text { length and 5-12 in width; indistinct hilum and lamellae }\end{array}$ & Poeae \\
\hline IV & $\begin{array}{l}\text { Polyhedral granules with pentagonal or hexagonal faces and rounded off edges; size range, 3-16 } \mu \mathrm{m} \text { in length and 2- } \\
15 \text { in width; centric distinct hilum; radial fissures; indistinct lamellae }\end{array}$ & Paniceae \\
\hline V & $\begin{array}{l}\text { Discoidal granules; size range, } 6-36 \mu \mathrm{m} \text { in length and } 4-30 \mu \mathrm{m} \text { in width; indistinct hilum; concentric, complete and } \\
\text { distinct lamellae; sometimes, longitudinal fissures were present. }\end{array}$ & Triticeae \\
\hline $\mathrm{VI}$ & $\begin{array}{l}\text { Ovoidal granules with flattened surfaces; size range, } 8-20 \mu \mathrm{m} \text { in length and 7-17 } \mu \mathrm{m} \text { in width; indistinct lamellae; deep } \\
\text { radial fissures starting from a centric hilum }\end{array}$ & Sorghum sp. \\
\hline
\end{tabular}




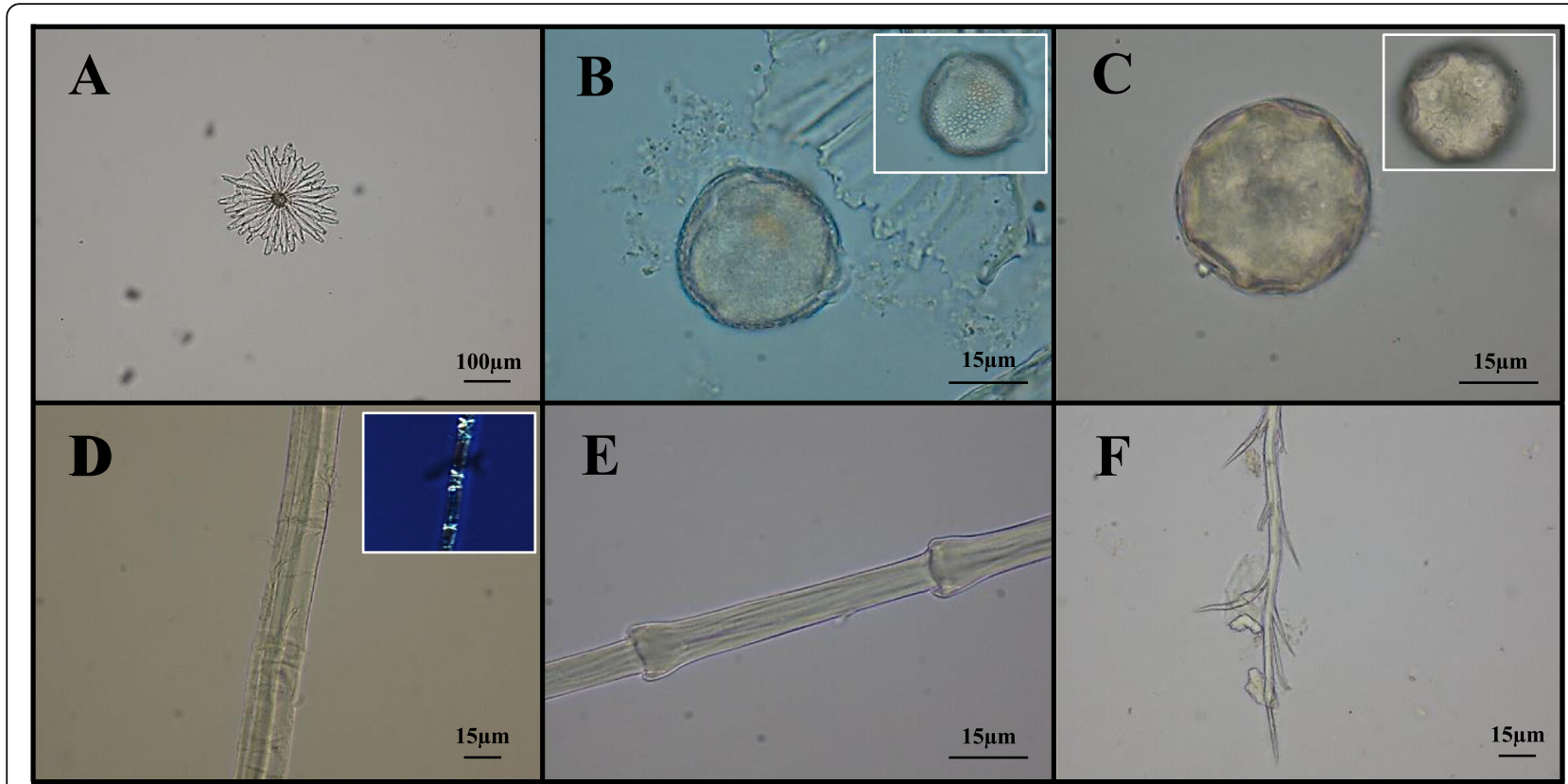

Fig. 3 Other micro-remains at light microscopy. Representative images of micro-debris found in dental calculus samples: peltate trichome of Olea sp. (a); Hedera pollen grain (b); Juglans regia pollen grain (c); plant fiber and relative polarized image (d); fragment of feather barbule typical of Anseriformes (e); bee hair (f)

ancient Mediterranean communities [65-68]. However, the most reliable hypothesis seems to be associated with ingestion of olive oil, as Romans used it in almost every dish [8].

\section{Animal micro-debris}

Among the microfossils, the identification of a branched bee hair appeared curious (Table 1, Fig. 3); it could be associated to consumption of honey or other beehive products [69]. Fragments of feather barbules were found in three individuals of the community (Table 1, Fig. 3). On the basis of its ring-shaped nodes regularly distributed along the structure, one of these micro-debris was attributed to the Galliformes order, which includes, for instance, chickens and pheasants. The other two fragments presented diagnostic triangular-shaped nodes typical of Anatidae family (Anseriformes, e.g., goose, duck) $[19,21,28,37]$. Another micro-remain showed morphological features ascribable to Cervidae (e.g., Cervus elaphus L.) or Bovidae (e.g., Capra sp. L.) hair (Table 1). Indeed, this hair showed a multicellular medulla with continuous pattern and structure partially filled lattice, although not well preserved [70]. These last findings were in line with the faunal remains found in many coeval archaeological sites and could have been inhaled during meat preparation (e.g., bird plucking) or derive from fragments of epidermis chewed during the meal. Both wild game and domestic animals, including pigeons, geese, deer, and goats, were exploited by the
Romans not only for meat, milk, and eggs, but also for their hides and antlers [6, 71-74].

\section{Gas chromatography mass spectrometry analysis}

GC-MS analysis produced significant results only for 20 individuals. In Additional file 2, the molecules identified in each sample of dental calculus were listed and clustered in biochemical classes. In all cases, replicates always showed similar chromatographic profiles. $\mathrm{N}$ alkanes and $n$-alkenes $\left(C_{4}\right.$ to $\left.C_{35}\right)$ were predominant components of all chromatograms, deriving from decomposition and degradation of oral microbiota or residues of animal or plant edibles [75-77]. These unspecific compounds were not reported in Additional file 2. The detection of methyl esters of saturated fatty acids (e.g., pentadecanoic; $n$-octadecanoic acids), together with unsaturated fatty acids (e.g., 9-octadecenoic; 9,12-octadecadienoic acids), could be considered indicators of consumption of animal fats or plant oils (e.g., oilrich seeds and fruits, like chestnuts and olives, also supported by previous microscopy evidence) [19, 78]. Polyunsaturated omega-3 fatty acids (e.g., EPA, DHA, and their derivatives), abundant in aquatic sources (e.g., molluscs, algae) and dried fruits (e.g., nuts, hemp seeds) [79], were detected in 9 specimens. Although oil-rich plant foods were commonly employed, the previous evidence could be also justified by consumption of a great variety of fish, or fish sauce (garum), as described by several Roman writers [80]. The presence of lactose and 11octadecenoic acid was indicative of ruminant milk and 
relative dairy products, widely consumed in the Roman period as alternative protein source, as much as legumes $[81,82]$. The identification of terpenes, terpenoids, and their derivatives (e.g., linalool, citronellol, nerolidol, epicubebol, globulol, origanene, menthol, levomenthol, ocimene) suggested the employment of Lamiaceae herbs, typical of Mediterranean area, as food preservatives and flavoring agents [83]. Similarly, other samples revealed the presence of sesquiterpene derivatives ascribable to Apiaceae species (e.g., santalol and shyobunol). In particular, the shyobunol might be considered a potential biomarker of Ferula sp. oil [84]. Ferula assa-foetida L. (commonly known as asafoetida) was widely used in ancient Rome as a culinary spice or for treating asthma, pneumonia, bronchitis, stomach-ache and flatulence [85]. Isothiocyanic acid, thiocyanic acid, isothiocyanate, isothiocyanatoacetaldehyde dimethyl acetal, and 13docosenoic acid were also detected by chromatographic analysis; they suggested the intake of cabbages and/or cauliflowers (generally Brassicaceae), which were typical Roman foods [86, 87]. The finding in one sample of tigogenin and smilagenin, two steroidal sapogenins, might indicate both the knowledge and the application of Trigonella foenum-graecum L., also called fenugreek [88, 89]. Indeed, Romans used seeds and leaves of this species as sources of food (rich in proteins), spices, drugs (for flatulence, dysentery, and dermatitis), and cosmetics $[90,91]$. Dental calculus of one individual presented of a fungal alkaloid, the ergosine, synthesized by Claviceps purpurea (Fr.) Tul [92]. As this parasite infests Poaceae species, the previous result suggested a potential contamination of the stored cereals. GC-MS analysis also identified other plant secondary metabolites ascribable to medicinal species, in detail, (i) two azulenes typical of Asteraceae inflorescences, like Matricaria chamomilla L. which was used as sedative and anti-inflammatory [14, 93]; (ii) the papaveroline, an isoquinoline alkaloid mainly contained in Papaver sp. L. [94], a genus employed in ancient cooking and medicine [95]; (iii) degradation forms of alkaloids (i.e., indole, isoindole, and piperidone) not attributable to specific plant sources; and (iv) digitoxin and cymarin, peculiar markers of Digitalis genus and Apocynaceae family, respectively, that were applied in traditional phytotherapy for curing cardiovascular disorders [96, 97]. In particular, digitoxin was detected in the individual of the tomb 23 , which was affected by ante-mortem compound fracture on both tibia and fibula; this evidence could suggest a potential use of Digitalis sp. extracts as powerful energizing drugs [98]. Two calculus samples revealed the presence of phytochemicals (i.e., tartaric acid and pyrogallol) diagnostic of wine [99, 100], an alcoholic beverage with a central role in Roman culture [13, 101, 102]. Indeed, although grape consumption dated back to Neolithic Age [18, 103], wine-making procedures were perfected only in GraecoRoman era [104]. Usually, wine was diluted in water, aromatized by natural flavoring substances (e.g., lavender, celery, myrtle, rose) or mixed with honey; this last habit might further support the detection of pollen grains in the samples [13]. Finally, the detection of humulol, in one individual, suggested the potential usage of Humulus lupulus L., the hop [105]. The inflorescence extract of this species was considered by Romans as a sedative (for insomnia and anxiety), while leaves and shoots were consumed as vegetables in salads $[106,107]$.

\section{Conclusions}

The archaeobotanical records obtained from dental calculus of the ancient inhabitants of the Ager Curensis allowed us outlining the subsistence pattern of this community. This work represents the first scientific study aimed at investigating diet habits and pharmacognosy of a Sabinian population. The detection of plant micro-remains and molecular markers, attributable to different types of cereals and other plant species, indicated a social group whose subsistence was mainly based on agriculture. Grain, such as oat, wheat, and sorghum, represented the main source of carbohydrates, while pulses and acorns provided the protein supply. Evidence of animal consumption also hypothesized husbandry, hunting, and beekeeping activities. Our data documented the putative application of phytotherapeutic remedies, suggesting both traditional knowledge and exploitation of the endemic flora. In particular, plant tissues from Lamiaceae, Apiaceae, Apocynaceae, Papaveraceae, Asteraceae, and Scrophulariaceae species were supposed to be used as raw materials for medicinal formulations. This work revealed the presence of both agricultural and wild species, usable for timber (e.g., chestnut), fiber (i.e., hemp), and food (e.g., olive) production, in the Roman Sabinian landscape. The notable botanical assemblage recorded in this research suggested that the studied community took advantage of multiple and varied natural resources, probably due to their proximity to the Tiber River and Rome. However, supplemental bioarchaeological sampling in the same context might offer further interesting insights about the rural economy of the Ager Curensis.

\section{Supplementary information}

Supplementary information accompanies this paper at https://doi.org/10. 1186/s13002-019-0334-z.

Additional file 1. Results of contamination control tests on ancient dental calculus before cleaning procedures. 
Additional file 2 The chemical compounds identified in dental calculus by GC-MS analysis, excluding $n$-alkanes and $n$-alkenes, were reported and classified in biochemical groups, for each sample.

\section{Abbreviations}

GC-MS: Gas chromatography mass spectrometry; EPA: Eicosapentaenoic acid; DHA: Docosahexaenoic acid

\section{Acknowledgments}

The authors want to thank Ing. Aldo Isi (CEO Italferr S.p.a.) and Ing. Gianpaolo Lavezzo (Italferr S.p.a.) for the support given to the initiative; Dr. Alessandro Betori (Funzionario responsabile di Zona - Ministero dei beni e delle attività culturali e del turismo - Soprintendenza Archeologia, Belle Arti e Paesaggio per le Province di Frosinone, Latina e Rieti) for the scientific coordination during the archaeological excavations; Mr. Francesco Colagrossi (Sindaco di Capranica Prenestina) which hosted the authors during the sampling at the "Museo Civico Naturalistico dei Monti Prenestini di Capranica Prenestina": CEDAD and Prof. Lucio Calcagnile for dating analyses; Prof. Cristina Martinez-Labarga; and Prof. Mauro Rubini (Responsabile Servizio Antropologia SABAP-Lazio Ministero dei Beni e delle Attività culturali e del Turismo) for their suggestions and comments about this research.

\section{Authors' contributions}

AG and AC designed research; MLC, RO, and TC performed the archaeoanthropological investigations; ADA and GDM carried out the sampling and performed the experiments; $D L$ provided her expertise in microscopy interpretation; $\mathrm{AG}, \mathrm{GDM}$, and $\mathrm{ADA}$ analyzed the data; $\mathrm{ADA}$ and $\mathrm{AG}$ wrote the paper; AC provided financial support; all authors edited, revised, and provided comments to the manuscript. All authors read and approved the final manuscript.

\section{Funding}

No funds were used to perform this research.

\section{Availability of data and materials}

Available within the paper

\section{Ethics approval and consent to participate}

Not applicable.

\section{Consent for publication}

Not applicable.

\section{Competing interests}

The authors declare that they have no competing interests.

\section{Author details}

'Department of Biology, University of Rome "Tor Vergata", Via della Ricerca Scientifica 1, 00133 Rome, Italy. "Società Cooperativa "II Bètilo" - Servizi per Beni Culturali a r. I., Via Remigio De Paolis 15, 00030 San Vito Romano (RM), Italy

Received: 3 May 2019 Accepted: 15 October 2019

Published online: 04 December 2019

\section{References}

1. Brucchietti E. Gli studi intrapresi da Caterina Montagna nella Sabina tiberina. Nuovi elementi per Cures e il suo territorio. In: Armellin P, La storia del territorio di Poggio Mirteto. Un racconto con il contributo di varie discipline. Poggio Mirteto 29 November 2014. 2018. p. 125-136.

2. Alvino G. Ricerche recenti della Soprintendenza per i beni Archeologici del Lazio nel territorio della provincia di Rieti. In: De Simone M, Formichetti G, Le ricerche archeologiche nel territorio sabino: attività, risultati e prospettive. Atti della giornata di studi. Rieti 11 May 2013. Rieti 2014.

3. Cavalieri M, Bigliardi G, Lenzi S, Fumo A, Deltenre F, Leporati C. Nuove ricerche archeologiche presso il sito di Cures Sabini: attività, ipotesi e prospettive. In FastiOnline, 8 (http://www.fastionline.org/docs/FOLDER-it-2 015-342.pdf).

4. Patterson $\mathrm{H}$. The middle Tiber Valley in the Late antique and Early Medieval periods: some observation. In: Patterson H, Coarelli F, Mercator
Placidissimus; the Tiber Valley in Antiquity. New research in the upper and middle river valley. Roma 27-28 February 2004. 2008. p. 499-532.

5. Belcastro G, Rastelli E, Mariotti V, Consiglio C, Facchini F, Bonfiglioli B. Continuity or discontinuity of the life-style in central Italy during the Roman imperial age-early middle ages transition: diet, health, and behavior. Am J Phys Anthropol. 2007;132:381-94.

6. Purcell N. The way we used to eat: diet, community, and history at Rome. Am J Philol. 2003;124:329-58.

7. Spurr MS. The cultivation of millet in Roman Italy. (Papers of the British School at Rome 51). British School at Rome. London 1983. pp. 1-15.

8. Murphy C, Thompson G, Fuller D. Roman food refuse: urban archaeobotany in Pompeii, Regio VI, Insula 1. Veg Hist Archaeobot. 2013;22:409-19. https:// doi.org/10.1007/s00334-012-0385-8.

9. Heinrich F. Modelling crop-selection in Roman Italy. The economics of agricultural decision making in a globalizing economy. In: de Haas TCA, Tol GW, The Economic Integration of Roman Italy. Rural communities in a globalizing world. Leiden: Brill; 2017. p. 141-69.

10. Killgrove K, Tykot RH. Food for Rome: a stable isotope investigation of diet in the imperial period (1st-3rd centuries AD). J Anthropol Archaeol. 2013;32 28-38.

11. Rowan E. Bioarchaeological preservation and non-elite diet in the Bay of Naples: an analysis of the food remains from the Cardo $V$ sewer at the Roman site of Herculaneum. Environ Archaeol. 2017;22:318-36. https://doi. org/10.1080/14614103.2016.1235077.

12. Nelson M. The barbarian's beverage: a history of beer in ancient Europe. Routledge. 2005.

13. Retief FP, Cilliers L. Wine in Graeco-Roman antiquity with emphasis on its effect on health. AASCIT J Health. 2015;2:44-9.

14. Petrovska BB. Historical review of medicinal plants' usage. Pharmacogn Rev. 2012;6:1-5.

15. Van der Veen M. Archaeobotany: the archaeology of human-plant interactions. In: Scheidel W, editor. The science of Roman history: biology, climate, and the future of the past. Princeton: Princeton University Press; 2018. p. 53-95.

16. Dikshit SS, Rai S, Sharma MM. Saga of ethnobotanical genesis from ancient to present scenario with special reference to the Darjeeling Himalayas. $J$ Med Plant. 2016;4:108-16.

17. Gismondi A, D'Agostino A, Canuti L, Di Marco G, Martínez-Labarga C, Angle M, Rickards O, Canini A. Dental calculus reveals diet habits and medicinal plant use in the Early Medieval Italian population of Colonna. J Archaeol Sci Rep. 2018;20:556-64

18. Gismondi A, Di Marco G, Martini F, Sarti L, Crespan M, Martínez-Labarga C, Rickards O, Canini A. Grapevine carpological remains revealed the existence of a Neolithic domesticated Vitis vinifera L. specimen containing ancient DNA partially preserved in modern ecotypes. J Archaeol Sci. 2016;69:75-84.

19. Gismondi A, D'Agostino A, Canuti L, Di Marco G, Basoli F, Canini A. Starch granules: a data collection of 40 food species. Plant Biosyst. 2019;153:273-9.

20. Bucher E. Lo spettro pollinico dei mieli dell'Alto Adige. Agenzia provinciale per la protezione dell'ambiente e la tutela del lavoro. Laboratorio biologico; 2004

21. Dove CJ, Koch SL. Microscopy of feathers: a practical guide for forensic feather identification. Microscope-Chicago. 2011;59:51.

22. Martin AC, Harvey WJ. The Global Pollen Project: a new tool for pollen identification and the dissemination of physical reference collections. Methods Ecol Evol. 2017;8:892-7.

23. PalDat- a palynological database (2000 onwards). 2019. www.paldat.org.

24. Baldoni M, Scorrano G, Gismondi A, D'Agostino A, Alexander M, Gaspari L, Vallelonga F, Canini A, Rickards O, Martinez-Labarga C. Who were the miners of Allumiere? a multidisciplinary approach to reconstruct the osteobiography of an Italian worker community. PLoS ONE. 2018;13: e0205362.

25. NIST, 2017. https://www.sisweb.com/software/ms/nist.htm.

26. FoodDB version 1.0. 2013. http://fooddb.ca/. Accessed 21 Dec 2018.

27. TGSC. The Good Scents Company. 2015. http://www. thegoodscentscompany.com/. Accessed 13 Dec 2018.

28. Cristiani E, Radini A, Edinborough M, Borić D. Dental calculus reveals Mesolithic foragers in the Balkans consumed domesticated plant foods. Proc Natl Acad Sci. 2016;113:10298-303.

29. Eerkens JW, Tushingham S, Brownstein KJ, Garibay R, Perez K, Murga E, Kaijankoskif P, Rosenthal JS, Gang DR. Dental calculus as a source of ancient alkaloids: detection of nicotine by LC-MS in calculus samples from the Americas. J Archaeol Sci Rep. 2018;18:509-15. 
30. Hendy J, Warinner C, Bouwman A, Collins MJ, Fiddyment S, Fischer R, Hagan R, Hofman CA, Holst M, Chaves E, Klaus L, Larson G, Mackie M, McGrath K, Mundorff AZ, Radini A, Rao H, Trachsel C, Velsko IM, Speller CF. Proteomic evidence of dietary sources in ancient dental calculus. Proc R Soc B. 2018;285:20180977.

31. Power RC, Salazar-García DC, Rubini M, Darlas A, Havarti K, Walker M, Hublin $J$ J, Henry AG. Dental calculus indicates widespread plant use within the stable Neanderthal dietary niche. J Hum Evol. 2018;119:27-41.

32. Hardy K, Buckley S, Collins MJ, Estalrrich A, Brothwell D, Copeland L, GarcíaTabernero A, García-Vargas S, de la Rasilla M, Lalueza-Fox C, Huguet R, Bastir M, Santamaría D, Madella M, Wilson J, Fernández Cortés Á, Rosas A. Neanderthal medics? Evidence for food, cooking, and medicinal plants entrapped in dental calculus. Naturwissenschaften. 2012;99:617-26.

33. Cummings LS, Yost C, Sołtysiak A. Plant microfossils in human dental calculus from Nemrik 9, a Pre-Pottery Neolithic site in Northern Iraq. Archaeol Anthropol Sci. 2018;10:883-91.

34. Lippi MM. The contribution of starch grain and phytolith analyses in reconstructing ancient diets. Fl Medit. 2018;28:287-94. https://doi.org/10. 7320/FIMedit28.287.

35. Lieverse AR. Diet and the aetiology of dental calculus. Int J Osteoarchaeol. 1999;9:219-32

36. Radini A, Nikita E, Buckley S, Copeland L, Hardy K. Beyond food: the multiple pathways for inclusion of materials into ancient dental calculus. Am J Phys Anthropol. 2017;162:71-83.

37. Cristiani E, Radini A, Borić D, Robson HK, Caricola I, Carra M, Mutri G, Oxilia G, Zupancich A, Šlaus M, Vujević D. Dental calculus and isotopes provide direct evidence of fish and plant consumption in Mesolithic Mediterranean. Sci Rep. 2018;8:8147.

38. ICSN. The international code for starch nomenclature. 2011. http://fossilfarm. org/ICSN/Code.html. Accessed 22 Apr 2018.

39. Murphy CA. Pompeii, a fully urban society: charting diachronic social and economic changes in the environmental evidence. Tijdschrift voor Mediterrane Archeologie. 2017

40. Sadori L, Susanna F. Hints of economic change during the late Roman Empire period in central Italy: a study of charred plant remains from "La Fontanaccia", near Rome. Veg Hist Archaeobot. 2005;14:386-93.

41. Murphy C. Finding millet in the Roman world. Archaeol Anthrop Sci. 2016;8:65-78.

42. Kamanatzis E. Agricultural practices in ancient Macedonia from the Neolithic to the Roman period. 2018. http://hdl.handle.net/11544/29152,

43. Cappers RTJ. Modelling shifts in cereal cultivation in Egypt from the start of agriculture until modern times. News from the past: progress in African archaeobotany: Proceedings of the 7th International Workshop on African Archaeobotany in Vienna, 2-5 July 2012. Barkhuis. 2016. p. 27.

44. Fuller DQ, Stevens CJ. Sorghum domestication and diversification: a current archaeobotanical perspective. In: Plants and People in the African Past. Cham: Springer; 2018. p. 427-52.

45. Mercuri AM, Fornaciari R, Gallinaro M, Vanin S, Di Lernia S. Plant behaviour from human imprints and the cultivation of wild cereals in Holocene Sahara. Nat plants. 2018;4:71

46. Copeland L, Hardy K. Archaeological Starch. Agronomy. 2018;8:4

47. Travaglini A, Arsieni A, Brighetti MA, Vinciguerra F. Atlante del polline delle principali specie allergeniche d'Italia. II Raggio Verde. Lecce; 2014.

48. Buonincontri MP, Saracino A, Di Pasquale G. The transition of chestnut (Castanea sativa Miller) from timber to fruit tree: cultural and economic inferences in the Italian peninsula. Holocene. 2015;25:1111-23.

49. Moser D, Nelle O, Di Pasquale G. Timber economy in the Roman Age: charcoal data from the key site of Herculaneum (Naples, Italy). Archaeol Anthrop Sci. 2018;10:905-21.

50. Carocho M, Calhelha RC, Queiroz MJR, Bento A, Morales P, Soković M, Ferreira IC. Infusions and decoctions of Castanea sativa flowers as effective antitumor and antimicrobial matrices. Ind Crop Prod. 2014;62:42-6.

51. Delaviz H, Mohammadi J, Ghalamfarsa G, Mohammadi B, Farhadi N. A review study on phytochemistry and pharmacology applications of Juglans regia plant. Pharmacogn rev. 2017;11:145.

52. Zumla A, Lulat A. Honey-a remedy rediscovered; 1989. p. 384-5.

53. Eteraf-Oskouei T, Najafi M. Traditional and modern uses of natural honey in human diseases: a review. Iran J Basic Med Sci. 2013;16:731.

54. The Textile Institute. The identification of textile materials. 7th ed. Manchester: The Textile Institute; 1985.

55. Bergfjord C, Holst B. A procedure for identifying textile bast fibres using microscopy: flax, nettle/ramie, hemp and jute. Ultramicroscopy. 2010;110: 1192-7.
56. Mercuri AM, Accorsi CA, Mazzanti MB. The long history of Cannabis and its cultivation by the Romans in central Italy, shown by pollen records from Lago Albano and Lago di Nemi. Veg Hist Archaeobot. 2002;11:263-76.

57. Kvavadze E, Bar-Yosef O, Belfer-Cohen A, Boaretto E, Jakeli N, Matskevich Z, Meshveliani T. Response to comment on "30,000-year-old wild flax fibers". Science. 2010;8:1634.

58. Bosi G, Mazzanti MB, Florenzano A, N'siala IM, Pederzoli A, Rinaldi R, Torri P, Mercuri AM. Seeds/fruits, pollen and parasite remains as evidence of site function: Piazza Garibaldi-Parma (N Italy) in Roman and Mediaeval times. J Archaeol Sci. 2011;38:1621-33.

59. Zemanek A, Zemanek B, Harmat, K, Madeja J, Klepacki P. Selected foreign plants in old polish botanical literature, customs and art (Acorus calamus, Aesculus hippocastanum, Cannabis sativa, Fagopyrum, Helianthus anuus, Iris). Plants and culture: seeds of the cultural heritage of Europe. Edipuglia, Bari; 2009. p. 179-193.

60. Singh M, Sardesai MM. Cannabis sativa (Cannabaceae) in ancient clay plaster of Ellora Caves. India. Curr Sci. 2016;110:884.

61. Gleba M, Harris S. The first plant bast fibre technology: identifying splicing in archaeological textiles. Archaeol Anthrop Sci. 2018:1-18.

62. Sperduti A, Giuliani MR, Guida G, Petrone PP, Rossi PF, Vaccaro S, Frayer DW, Bondioli L. Tooth grooves, occlusal striations, dental calculus, and evidence for fiber processing in an Italian eneolithic/bronze age cemetery. Am J Phys Anthropol. 2018;167:234-43.

63. Montanari AA. I fiori del male. Opium, cannabis e piante psicoattive nel Medioevo. I quaderni del m. æ. s. J. Mediæ Ætatis Sodalicium. 2010;13:105-24.

64. Butrica JL. The medical use of cannabis among the Greeks and Romans. J Cann Therap. 2002;2:51-70.

65. Wainstein J, Ganz T, Boaz M, Bar Dayan Y, Dolev E, Kerem Z, Madar Z. Olive leaf extract as a hypoglycemic agent in both human diabetic subjects and in rats. J Med Food. 2012;15:605-10.

66. Sabry OM. Beneficial health effects of olive leaves extracts. J Nat Sci Res. 2014;4:1-9.

67. Cinti T, Lo CM. L'olio tra fede, medicina e cucina. In: Oleum et agri. Ruralità e paesaggio culturale - Recuperi archeologici della Guardia di Finanza in mostra a San Vito Romano. Gangemi Editore; 2015. p. 25

68. Hashmi MA, Khan A, Hanif M, Farooq U, Perveen S. Traditional uses, phytochemistry, and pharmacology of Olea europaea (olive). Evid Based Complement Alternat Med. 2015. https://doi.org/10.1155/2015/541591.

69. Kvavadze E, Sagona A, Martkoplishvili I, Chichinadze M, Jalabadze M, Koridze I. The hidden side of ritual: new palynological data from Early Bronze Age Georgia, the Southern Caucasus. J Archaeol Sci Rep. 2015;2:235-45.

70. Sari A, Arpacik A. Morphological hair identification key of common mammals in turkey. Appl Ecol Env Res. 2018;16:4593-603.

71. Grivetti LE. Mediterranean food patterns: the view from antiquity, ancient Greeks and Romans. In: In the Mediterranean diet. Constituents and health promotion. Boca Raton: CRC Press; 2001.

72. Faas P. Around the Roman table: food and feasting in ancient Rome: University of Chicago Press; 2005

73. Redfern RC, Hamlin C, Athfield NB. Temporal changes in diet: a stable isotope analysis of late Iron Age and Roman Dorset. Britain. J Archaeol Sci. 2010;37:1149-60.

74. Pate FD, Henneberg RJ, Henneberg M. Stable carbon and nitrogen isotope evidence for dietary variability at ancient Pompeii, Italy. Mediterr Archaeol Archaeom Int J. 2016;16.

75. Eglinton G, Gonzalez AG, Hamilton RJ, Raphael RA. Hydrocarbon constituents of the wax coatings of plant leaves: a taxonomic survey. Phytochemistry. 1962;1:89-102.

76. Evershed RP, Heron C, Charters S, Goad LJ. The survival of food residues: new methods of analysis, interpretation and application. In: Proceedings of the British Academy; 1992. p. 2.

77. Buckley SA, Stott AW, Evershed RP. Studies of organic residues from ancient Egyptian mummies using high temperature-gas chromatography-mass spectrometry and sequential thermal desorption-gas chromatography-mass spectrometry and pyrolysis-gas chromatography-mass spectrometry. Analyst. 1999;124:443-52.

78. Kanthilatha N, Boyd W, Dowell A, Mann A, Chang N, Wohlmuth H, Parr J. Identification of preserved fatty acids in archaeological floor sediments from prehistoric sites at Ban Non Wat and Nong Hua Raet in northeast Thailand using gas chromatography. J Archaeol Sci. 2014;46:353-62.

79. Swanson D, Block R, Mousa SA. Omega-3 fatty acids EPA and DHA: health benefits throughout life. Adv Nutr. 2012;3:1-7. 
80. Dalby A. Food in the ancient world from A to Z. Routledge. 2013.

81. Destaillats F, Buyukpamukcu E, Golay PA, Dionisi F, Giuffrida F. Letter to the Editor: vaccenic and rumenic acids, a distinct feature of ruminant fats. J Dairy Sci. 2005;88:449.

82. Borstad CM, Garvie-Lok S, Katsonopoulou D. Diet at ancient Helike, Achaea, Greece based on stable isotope analysis: from the Hellenistic to the Roman and Byzantine periods. J Archaeol Sci Rep. 2018;18:1-10.

83. Shaaban HA, Moawad SA. Chemical composition, nutritional and functional properties of some herbs and spices. Curr Sci. 2017;3:165-79.

84. Benchabane O. Chemical composition and insecticidal activities of essential oils of two Algerian endemic plants: Ferula vesceritensis Coss. et Dur. and Thymus pallescens de Noe. Int J Agric Sci Res. 2014;4:185-91.

85. Gholamnezhad Z, Byrami G, Boskabady MH, Iranshahi M. Possible mechanism (s) of the relaxant effect of asafoetida (Ferula assa-foetida) oleogum-resin extract on guinea-pig tracheal smooth muscle. Avicenna J Phytomed. 2011;2:10-6.

86. Ermolli ER, Romano P, Ruello MR, Lumaga MRB. The natural and cultural landscape of Naples (southern Italy) during the Graeco-Roman and Late Antique periods. J Archaeol Sci. 2014;42:399-411.

87. Bell L, Wagstaff C. Enhancement of glucosinolate and isothiocyanate profiles in Brassicaceae crops: addressing challenges in breding for cultivation, storage, and consumer-related traits. J Agric Food Chem. 2017;65:9379-403.

88. Madhu A, Mala A, Jain SC. In vitro regulation of bioactive compounds in Trigonella species by mutagenic treatments. J Plant Sci. 2015;3:40-4.

89. Aasim M, Baloch FS, Nadeem MA, Bakhsh A, Sameeullah M, Day S, Fenugreek (Trigonella foenum-graecum L.): an underutilized edible plant of modern world. In: Global perspectives on underutilized crops. Cham: Springer; 2018. p. 381-408.

90. El-Wakf AM, Hassan HA, Mahmoud AZ, Habza MN. Fenugreek potent activity against nitrate-induced diabetes in young and adult male rats. Cytotechnology. 2015;67:437-47.

91. Staub PO, Casu L, Leonti M. Back to the roots: a quantitative survey of herbal drugs in Dioscorides' De Materia Medica (ex Matthioli, 1568). Phytomedicine. 2016;23:1043-52.

92. Maruo VM, Bracarense AP, Metayer JP, Vilarino M, Oswald IP, Pinton P. Ergot alkaloids at doses close to eu regulatory limits induce alterations of the liver and intestine. Toxins. 2018;10:183.

93. Siadat SA, Direkvand-Moghadam F. The study of essential oil composition of Matricaria chamomilla in Khouzestan. Adv Herb Med. 2016;2:1-5.

94. Cilliers $L$, Retief F. Poisons, poisoners, and poisoning in ancient Rome. In Toxicology in Antiquity. Academic Press. 2019. p. 231-242.

95. Merlin MD. Archaeological evidence for the tradition of psychoactive plant use in the old world. Econ Bot. 2003;57:295-323.

96. van Tellingen C. Pliny's pharmacopoeia or the Roman treat. Neth Heart J. 2007;15:118-20

97. Rastogi S, Pandey MM, Rawat AKS. Traditional herbs: a remedy for cardiovascular disorders. Phytomedicine. 2016;23:1082-9.

98. Weiss RF. Herbal Medicine. In: Meuss AR, editor. Lehrbuch der Phytotherapie. Beaconsfield, England: Beaconsfield Publishers Itd; 2000. p. 1 11.

99. Guasch-Jané MR, Ibern-Gómez M, Andrés-Lacueva C, Jáuregui O, LamuelaRaventós RM. Liquid chromatography with mass spectrometry in tandem mode applied for the identification of wine markers in residues from ancient Egyptian vessels. Anal Chem. 2004;76:1672-7.

100. Milanesi C, Bigliazzi I, Faleri C, Caterina B, Cresti M. Microscope observations and DNA analysis of wine residues from Roman amphorae found in Ukraine and from bottles of recent Tuscan wines. J Archaeol Sci. 2011;38:3675-80.

101. Stanley PV. Gradation and quality of wines in the greek and roman worlds. J Wine Res. 1999:10:105-14.

102. Nikolić VM. The role of wine in transition ceremonies and certain holiday traditions. Istraživanja. J Hist Res. 2016:5-17.

103. Marvelli S, De'Siena S, Rizzoli E, Marchesini M. The origin of grapevine cultivation in Italy: the archaeobotanical evidence. Ann Bot. 2013;3:155-63.

104. Unwin T. Wine in the Graeco-Roman economy. In: Wine and the vine: an historical geography of viticulture and the wine trade. Routledge, UK: London. 1st edition; 2005.

105. Bocquet L, Sahpaz S, Hilbert JL, Rambaud C, Rivière C. Humulus lupulus L., a very popular beer ingredient and medicinal plant: overview of its phytochemistry, its bioactivity, and its biotechnology. Phytochem Rev. 2018; 17:1047-90.
106. Renner SS, Scarborough J, Schaefer H, Paris HS, Janick J, Pitrat M. Dioscorides's Bruonia melaina is Bryonia alba, not Tamus communis, and an illustration labeled Bruonia melaina in the Codex Vindobonensis is Humulus lupulus not Bryonia dioica. In: Pitrat M editor. Cucurbitaceae. 2008. Proceedings of the IXth EUCARPIA meeting on genetics and breeding of Cucurbitaceae, Avignon (France), May 21-24 $4^{\text {th }} ; 2008$. p. 273-280.

107. Zanoli P, Zavatti M. Pharmacognostic and pharmacological profile of Humulus lupulus L. J Ethnopharmacol. 2008;116:383-96.

\section{Publisher's Note}

Springer Nature remains neutral with regard to jurisdictional claims in published maps and institutional affiliations.
Ready to submit your research? Choose BMC and benefit from:

- fast, convenient online submission

- thorough peer review by experienced researchers in your field

- rapid publication on acceptance

- support for research data, including large and complex data types

- gold Open Access which fosters wider collaboration and increased citations

- maximum visibility for your research: over $100 \mathrm{M}$ website views per year

At BMC, research is always in progress.

Learn more biomedcentral.com/submissions 